\title{
Removal of natural organic matter in waters using hydrodynamic cavitation and hydrogen peroxide (HC-H2O2)
}

\author{
Remoção de matéria orgânica natural em águas usando cavitação \\ hidrodinâmica e peróxido de hidrogênio $\left(\mathrm{CH}-\mathrm{H}_{2} \mathrm{O}_{2}\right)$
}

\author{
Matheus Neves de Araujo' \\ Thiago Vinicius Ribeiro Soeira" \\ Cristiano Poleto'II \\ Elias Gabriel Fernandes de Rezende ${ }^{\text {IV }}$ \\ Otávio Augusto Puglieri Cappav \\ Deusmaque Carneiro FerreiraVI \\ Vinícius Carvalho Rochaviı \\ Julio Cesar de Souza Inácio Gonçalves ${ }^{\mathrm{III}}$
}

\begin{abstract}
The presence of natural organic matter (NOM) in water does not present direct risk to the human body or to the environment. However, its presence along with other pollutants can lead to countless issues and damage human health and the environment. The hydrodynamic cavitation (HC) phenomenon started being used in the early $21^{\text {st }}$ century as a process capable of treating supply-water and wastewater based on pollutant and pathogen degradation. Process effectiveness increases when it is combined to chemical agents, creating an advanced oxidation process (AOP). Although several studies have presented broaden applications for the HC process, its use for NOM removal from supply-water was not yet assessed; therefore, it remains a gap in scientific knowledge. The aim of the current study is to assess HC potential in NOM removal. In order to do so, the experiments were carried out in bench scale hydrodynamic cavitation system operated at batch model within 15-min duration period-of-time. In addition, decantation experiments (24-h period-of-time) were performed in order to check $\mathrm{HC}$ influence on molecules found in reaction medium after the exposure of NOM to the phenomenon. NOM was produced by a synthetic humic acid (HA) matrix at fixed concentration of 100 ppm. In total, 16 experiments were carried out; each experiment was featured by the following pair: pH (2.6, 3.0, 3.5 and 5.5$)$ and hydrogen peroxide $(0,1,5$ and $30 \mathrm{~mL})$. The best removal efficiencies $(34 \%-36 \%)$ were observed in the most acidic $\mathrm{pH}$ ranges (2.6-3.0) at $\mathrm{H}_{2} \mathrm{O}_{2}$ concentration of $15 \mathrm{~mL}$. Results have presented high NOM removal efficiency (approximately $90 \%$ ) after decantation at the most acidic $\mathrm{pH}$ ranges, as well. It can be explained by the fact that hydrodynamic cavitation in acid solution can break molecular structures suspended in the liquid medium, which favors decantation. Based on the present study, hydrodynamic cavitation with
\end{abstract}

'Federal University of Triângulo Mineiro, Uberaba, MG, Brasil - matheusnevesaraujo1@gmail.com.

"Federal University of Triângulo Mineiro, Uberaba, MG, Brasil - tvribeiro88@hotmail.com.

I'IFederal University of Rio Grande do Sul, Porto Alegre, RS, Brasil - cristiano.poleto@ufrgs.

IVFederal University of Triângulo Mineiro, Uberaba, MG, Brasil - eliasgrf@yahoo.com.br.

$v^{\vee}$ Federal University of Triângulo Mineiro, Uberaba, MG, Brasil - otavio.puglieri@gmail.com.

$\mathrm{V}^{\mathrm{V}}$ Federal University of Triângulo Mineiro, Uberaba, MG, Brasil - deusmaque@hotmail.com.

VIIFederal University of Triângulo Mineiro, Uberaba, MG, Brasil - viambiental2005@gmail.com.

VIIIFederal University of Triângulo Mineiro, Uberaba, MG, Brasil - julio.goncalves@uftm.edu.br. 
hydrogen peroxide addition can remove NOM from water; moreover, $\mathrm{pH}$ control is an essential factor for process development.

Keywords: Advanced oxidative process; Orifice plate; Hydrodynamic cavitation.

\section{Resumo}

A presença de matéria orgânica natural (MON) em águas não apresenta riscos diretos relacionados ao seu contato com o organismo humano e nem mesmo ao meio ambiente. Entretanto, sua presença, em conjunto a outros poluentes, pode acarretar inúmeros problemas e danos à saúde humana e ao meio ambiente. $O$ fenômeno de cavitação hidrodinâmica $(\mathrm{CH})$ passou a ser utilizado no início do século XXI como um processo capaz de realizar o tratamento de águas de abastecimento ou residuárias a partir da degradação de poluentes e patógenos. A efetividade do processo aumenta quando aliado à adição de agentes químicos no meio reacional, configurando um processo oxidativo avançado (POA). Por mais que diversos trabalhos apresentem amplas aplicações para o processo de $\mathrm{CH}$, sua utilização para remoção de $\mathrm{MON}$ de águas de abastecimento ainda não foi avaliada e, portanto, apresenta-se como uma lacuna no conhecimento científico. O objetivo deste trabalho é avaliar o potencial da $\mathrm{CH}$ em remover MON. Para tanto, os experimentos foram realizados em um sistema de cavitação hidrodinâmica, em escala de bancada, operado em modo batelada com duração de 15 minutos. Adicionalmente, experimentos de decantação (período de 24 horas) foram conduzidos com intuito de verificar a influência da $\mathrm{CH}$ sobre as moléculas presentes no meio reacional após exposição ao fenômeno. A MON foi constituída por uma matriz de ácido húmico $(\mathrm{AH})$ sintética à uma concentração fixa de 100 ppm. No total foram realizados 16 experimentos, no qual cada experimento foi caracterizado pelo par: $\mathrm{pH}(2,6 ; 3,0$; 3,5; e 5,5) e peróxido de hidrogênio $(0 ; 1 ; 15$ e $30 \mathrm{~mL}$ ). As melhores eficiências de remoção (34-36\%) foram encontradas para faixas de $\mathrm{pH}$ mais ácidas $(2,6-3,0)$, para uma concentração de $15 \mathrm{~mL}$ de $\mathrm{H}_{2} \mathrm{O}_{2}$. Após decantação, os resultados apresentaram uma elevada eficiência de remoção de MON (aproximadamente 90\%), também para faixas de $\mathrm{pH}$ mais ácidas. Isso pode ser explicado pelo fato de que, em soluções ácidas, a cavitação hidrodinâmica consegue romper estruturas moleculares suspensas no meio líquido, favorecendo a decantação. Este estudo mostrou que a cavitação hidrodinâmica aliada a peróxido de hidrogênio é capaz de remover MON presentes em águas e que o controle do pH é fator crucial para o desempenho do processo.

Palavras-chave: Processo oxidativo avançado; Placa de orifício; Cavitação hidrodinâmica. 


\section{Introduction}

A whole variety of chemical compounds was introduced in Consolidation Legal ordinance n. 5, from September 28th, 2017, which was issued by the Ministry of Health (Brazilian Legislations in force - accountable for presenting standardized drinking water parameters that represent a risk to human health, as well as its allowed maximum values). The organic chemical compound class is among these parameters, mainly when it comes to human activities.

An important natural water component is indirectly parametrized through the socalled disinfection byproducts (DBP). This class of pollutant is generated through reaction between chemical reagents used in water disinfection in treatment stations and a class of substances called natural organic matter (NOM); these reactions can lead to severe disorders in human health. Thus, avoiding mechanisms accountable for the formation of these species is extremely important for human health and environmental maintenance (FILHO and SAKAGUTI, 2008; SILVA and MELO, 2015). In addition, Lopes Silva et al. (2020) have also shown that NOM, besides allowing BDPs' formation, can reduce waterbodies' selfdepuration ability, since NOM molecules form a film in the air-water interface; this film makes oxygen transfer to water more difficult.

NOM in natural water, mainly in high-turbidity surface fresh water, encompasses a whole variety of organic chemical compounds that present several functional groupings and different molecular weights, which makes it possible featuring three fractions: hydrophobic, hydrophilic and transphilic. The hydrophobic fraction comprises high molecular weight substances that mostly show aromatic carbon that configures phenolic structures and conjugated double bonds. Besides having the largest fraction of NOM in aquatic environments, the hydrophobic fraction accounts for approximately $50 \%$ of the dissolved organic carbon (DOC) in natural water. The hydrophilic fraction comprises lower molecular weight substances that present aliphatic carbons and nitrogenous constituents such as carbohydrates, proteins, sugars and amino acids, and correspond for the DOC range from $25 \%$ to $40 \%$ observed in natural water. Finally, the transphilic fraction encompasses 
intermediate molecular weight molecules between the hydrophobic and hydrophilic fractions; besides it presents approximately $25 \%$ of DOC observed in hydric resources $(\mathrm{CHOl}$, 2003; ŚWIETLIK et al., 2004; THURMAN, 1985).

NOM hydrophobic fraction is called humic substances (HS) represented by complex macromolecules accountable for retaining approximately $50 \%$ of all carbon on the globe (JONES; BRYAN, 1998). According to Choi (2003), besides representing the biggest NOM fraction in the environment, $\mathrm{HSs}$ account for approximately $70 \%-80 \%$ of total organic carbon (TOC) in the soil and for $60 \%-90 \%$ of all DOC in natural water. The DOC divergence in natural water presented by Choi (2003) and Thurman (1985) can be explained through climatic seasonal variation in environments that influence the concentrations of these substances in aquatic ecosystems (LIN, 2000).

The most efficient way to avoid DBPs in supply-water lies on efficient natural organic matter removal. Consolidated processes such as complete and alternative cycles, which are also based on coagulation and filtration, are efficient in removing natural organic matter (NOM) fractions. However, due to high implementation costs and station operation of complete cycles for mid- and small-sized communities, as well as to manpower and resource scarcity for the adoption of consolidated alternative methods, the search for new treatment technologies is essential for the context that encompasses human health maintenance and efficient and less costly processes (DI BERNARDO; PAZ, 2007).

Advanced oxidation processes (AOPs) have being extensively studied for the aforementioned purpose. Sanly et al. (2007) obtained a maximum DOC removal efficiency of 33\% for a synthetic HA matrix after one-hour treatment with UV254/H2O2. Other studies that used synthetic HA matrices showed higher DOC or TOC removal, for instance: 80\% DOC removal at 150-min treatment by using TiO2/UVA365 (LIU et al., 2008); 93\%-98\% TOC removal by using TiO2 nanotube/LP UV linked to membrane filtration (ZHANG et al. 2009); $80 \%$ TOC removal after 15 -h treatment by using Reagent Fenton/UV (KATSUMATA et al. 2008); $78 \%$ TOC removal by using H2O2/O3 for 20-min treatment (ALSHEYAB; MUÑOZ, 2006). 
Hydrodynamic cavitation $(\mathrm{HC})$ is one of the alternatives emerging as efficient to remove water pollutants (BATISTA; ANHÊ; GONÇALVES, 2017; ALVES et al., 2019; MACHADO et al., 2020). It is generated by liquid passage through physical constriction (cavitation chamber), such as an orifice plate and a Venturi. When the liquid pressure in constriction section falls below its vapor pressure, microbubbles are generated; subsequently, they implode when liquid pressure is recovered downstream the constriction section. Overall, hydrodynamic cavitation can be understood as a phenomenon of formation, growth and implosion (collapse) of vapor microbubbles (cavities) in a liquid medium (RAJORIYA et al., 2018). This phenomenon takes place within small time intervals and releases a great amount of energy, as the consequence of the formation of high temperature (1.000 to $10000 \mathrm{~K}$ ) and pressure (10 and $500 \mathrm{Mpa}$ ) regions (GOGATE; KABADI, 2009). Besides physical changes, Gagol et al. (2018) consider that two fundamental oxidative processes can occur during the cavitation phenomenon for pollutant degradation: the direct pollutant decomposition by pyrolysis and the water molecules decomposition by pyrolysis that produce high redox potential chemical species, which can subsequently react with pollutant molecules.

In addition to water molecules, other compounds, such as hydrogen peroxide ( $\left.\mathrm{H}_{2} \mathrm{O} 2\right)$ and ozone (O3), can form high redox potential species when they are exposed to the cavitation process. The insertion of these substances in the reaction medium can lead to better efficiency in the formation of highly reactive species and, consequently, account for the effective pollutant degradation through HC.

Although the oxidant is an important component of the treatment associated with hydrodynamic cavitation, the optimum dose of this compound must be experimentally defined depending on the device (orifice plate or Venturi) and pollutant type to be treated, since lack or excess of it can result in significant loss of efficiency in the treatment. Peroxide excess can generate secondary reactions that form radicals presenting lower-degradation potential (RAUT-JADHAV et al., 2016; BAGAL, M.V., GOGATE, 2013; PATIL, BOTE and GOGATE, 2014).

Another factor influencing pollutant removal efficiency lies on the geometry of the cavitation chamber. Alves et al. (2019) have shown that the Venturi chamber is more efficient 
in removing sucrose than the orifice plates. On the other hand, they have also shown that Venturi can produce cavitation clouds under certain pressure conditions. Cavitation clouds can reduce cavity collapse intensity and, consequently, pollutant removal efficiency (CAPPA et al., 2020).

Accordingly, the aim of the present study was to assess the NOM removal potential through HC process associated with hydrogen peroxide. For this purpose, a unique hydrodynamic cavitation chamber - represented by an orifice plate presenting three different thicknesses - was used in the experiment; it was built in order to avoid cavitation clouds. Additional aims were: 1. Evaluating the influence of $\mathrm{pH}$ on NOM removal efficiency; 2. Evaluating the hydrogen peroxide proportions on NOM removal; 3. Evaluating the influence of NOM removal by adding a new process to the treatment system - decantation.

\section{Materials and Methods}

\subsection{Hydrodynamic cavitation system}

The schematic design of the experimental apparatus used in the present study is shown in Figure 1. The system was built in closed circuit and encompassed a feeding tank (9-I in volume); a series pumping system composed of two pumps: a peripheral pump "G1" of 1cv power (KSB ${ }^{\circledR}$ Hydrobloc, P1000 model) and a centrifugal pump "G2" of 1.5cv power (THEBE THA-16 Al); control valve "E", digital manometer "I"; wattmeter " $\mathrm{F}$ "; cavitation chamber; pipes and connections. The cavitation chamber consists of a plate with three different thicknesses $(1 \mathrm{~mm}, 8 \mathrm{~mm}$ and $15 \mathrm{~mm}$ ) and 9 holes (1mm in diameter, each). This plate was dimensioned in order to better distribute the cavities in the hydrodynamic cavitation chamber and to minimize the existence of cavitation clouds.

Experiments temperature was controlled by using a heat exchanger composed of copper pipe and pump for cold water recirculation. Mean temperature was close to $35^{\circ} \mathrm{C}$. The flow rate was controlled by the " $E$ " valve and measured by using a properly calibrated orifice plate " $\mathrm{C}$ " (flow coefficient $C_{d}=0.70$ ). 
The cavitation chamber performance in removing NOM was assessed considering an inlet pressure P1 of 7.3 bar. The following water features were reached due to this pressure: $\mathrm{P} 2=1.143$ bar; average flow rate $=0.176 \mathrm{~L} \mathrm{~s}^{-1}$; and flow velocity $=24.84 \mathrm{~m} \mathrm{~s}^{-1}$ (in orifices).

Figure 1 - Schematic design of the experimental apparatus. P1 and P2 are the inlet and outlet pressures in the cavitation chamber; G1 and G2 are the pumps placed in series; "I" is the digital manometer; $\mathrm{F}$ is the wattmeter; $\mathrm{C}$ is the orifice plate to measure flow rate; $\mathrm{D} 1$ and $D 2$ are the pressure taps to measure flow rate; $E$ is the flow rate control valve; $A$ and $B$ are the inlet and outlet of the heat exchanger, respectively

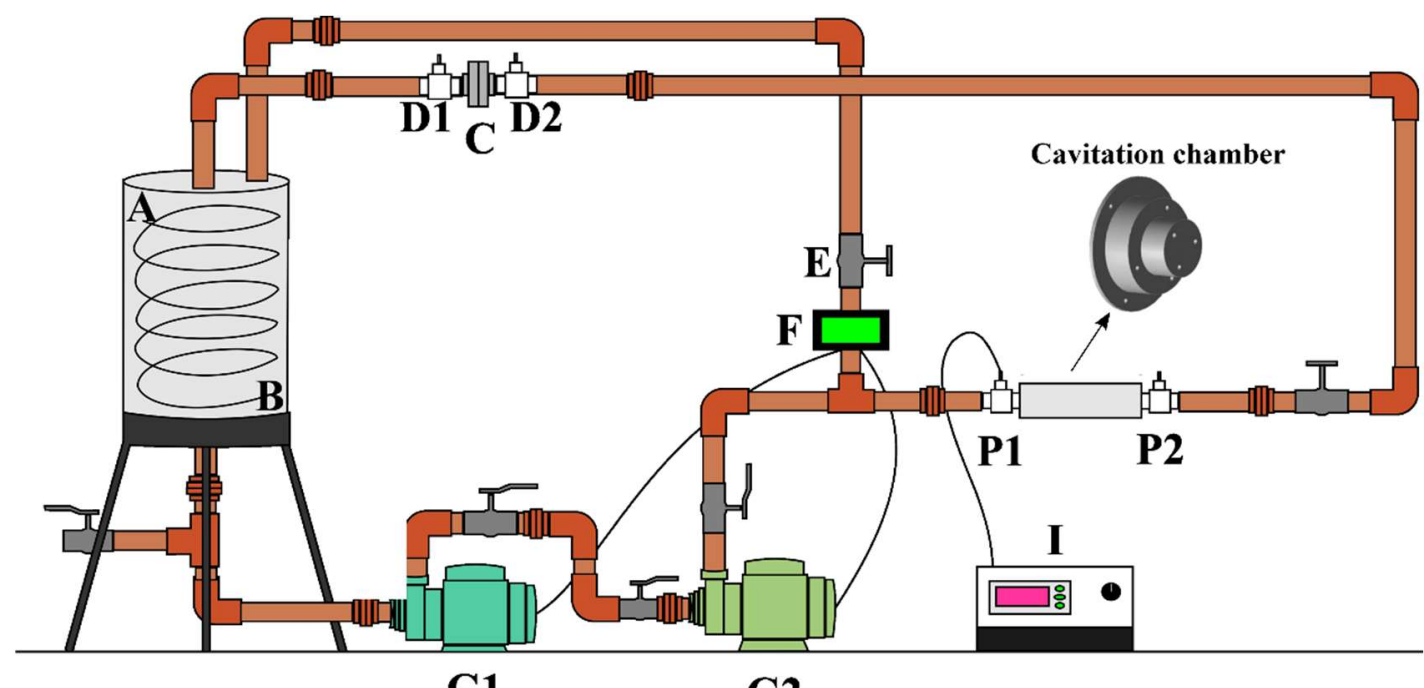

G1

G2

\subsection{Synthetic supply-water}

A synthetic humic acid (Sigma-Aldrich) solution was produced and used as a substrate to be treated in the hydrodynamic cavitation apparatus. It was done in order to simulate natural water presenting significant NOM amount.

In total, 200L of synthetic humic acid solution were prepared at $100 \mathrm{ppm}$ concentration. Samples of 9 liters were filtered in filter paper to eliminate possible solids and to assure greater homogenization. Their $\mathrm{pH}$ values were corrected by adding PA hydrochloric acid addition according to the need of each proposed experiment. Finally, samples were stored in previously cleaned gallons for further use. 


\subsection{Experimental project and analysis methods}

The hydrodynamic cavitation system was operated for a period of 15 minutes. Aliquots of approximately $50 \mathrm{~mL}$ were collected within 3-min time intervals $\left(0^{\prime}, 3^{\prime}, 6^{\prime}, 9^{\prime}, 12^{\prime}\right.$ and $15^{\prime}$ ) during the adopted treatment time. A total of 20 experiments were performed as a result of varying the $\mathrm{pH}$ values and volume of peroxide of the samples. The assessed $\mathrm{pH}$ values were 2.6, 3.0, 3.5 and 5; each one of these values was subjected to assays based on the addition of the following volumes of $50 \%$ PA hydrogen peroxide $(\mathrm{m} / \mathrm{m}): 0 \mathrm{~mL}, 1 \mathrm{~mL}, 15$ $\mathrm{mL}$ and $30 \mathrm{~mL}$. It is important highlighting that hydrogen peroxide was added to the reservoir of the cavitation apparatus prior to the beginning of each experiment.

After the treatment, $15 \mathrm{~mL}$ of solution was removed from each aliquot and sent for total organic carbon (TOC) analysis, which was carried out in Shimadzu TOC-5000 APC. This analysis allowed determining NOM removal efficiency due to humic acid matrix oxidation through the hydrodynamic cavitation phenomenon. The remaining treated solution $(35 \mathrm{~mL})$ were left to rest for $24-\mathrm{h}$ so that the decantation phenomenon could happen. After this period-of-time, $15 \mathrm{~mL}$ of the supernatant liquid was removed and once more sent for TOC analysis. Accordingly, it was possible quantifying total NOM removal as result from the oxidation and decantation phenomena. Calculations used to determine the removal efficiency of the hydrodynamic cavitation phenomenon and of the decantation phenomenon associated with cavitation are presented in Equations 1 and 2, respectively:

$$
O R_{i}=\left(\frac{C_{0}-C_{i}}{C_{0}}\right) \times 100
$$

Wherein,

$O R_{\mathrm{i}}$ is TOC removal efficiency (NOM) due to the hydrodynamic cavitation phenomenon (Oxidation);

$C_{0}$ is the initial TOC concentration of the gross sample; and

$C_{i}$ is the TOC concentration of the sample at time i.

$$
R T_{i}=\left(\frac{C_{0}-C_{24 D i}}{C_{0}}\right) \times 100
$$

Wherein, 
$R T_{i}$ is the TOC removal efficiency (NOM) due to the hydrodynamic cavitation phenomenon associated with the decantation phenomenon.

$C_{0}$ is the initial TOC concentration of the gross sample; and

$\mathrm{C}_{24 \mathrm{Di}}$ is the TOC concentration in the sample after $24-\mathrm{h}$ rest in decantation based on the respective treatment time i through the hydrodynamic cavitation process.

\section{Results and Discussion}

\subsection{NOM removal through hydrodynamic cavitation}

Figure 2 presents results of NOM reduction rate recorded for different analyzed hydrogen peroxide volumes and $\mathrm{pH}$ values. It was observed that the hydrodynamic cavitation was capable of degrading fractions of humic acid matrix and that variable $\mathrm{pH}$ had strong influence on this process. The most acidic $\mathrm{pH}$ ranges have presented the best TOC removal efficiencies of the HA matrix; as $\mathrm{pH}$ value increased, efficiency slowly reduced. These results corroborate the studies presented by GAGOL et al. (2018), RAUT-JADHAV et al. (2013) and GOGATE and BHOSALE (2013). The stability of the hydroxyl radical precursor, hydrogen peroxide, was assured through high acidity; this reagent became unstable in more basic media - this finding corroborated with the effect observed in Figure 2.

The maximum efficiency (36.48\%) was obtained for the sample of $\mathrm{pH} 3.0$ and peroxide dosage of $15 \mathrm{~mL}$, at treatment time of 15 -min. There was efficiency increase trend at $\mathrm{pH}$ ranges 2.6 and 3.0 due to time; this outcome indicates that removal increases in case treatment time is longer than 15-min. Samples at pH of 3.5 also suggest possible continuity of NOM removal; however, there was considerable reduction in $\mathrm{pH}$ increase rate. On the other hand, samples at $\mathrm{pH}$ of 5.5 have shown stability rate in removal efficiency after 3-min treatment. This finding highlights the possible stagnation in HA matrix degradation, if experiments exceed the time adopted for the protocol.

Although hydrogen peroxide emerged as essential for NOM removal, the optimum dose (15 mL, for $\mathrm{pH}$ values 2.6 and 3.0) did not meet the largest volume used in the experiment $(30 \mathrm{~mL})$. It could have happened because peroxide excess can lead to secondary 
reactions capable of forming radicals with lower degradation potential (RAUT-JADHAV et al., 2016; PATIL et al., 2014; BAGAL; GOGATE, 2013 and MACHADO et al., 2020). This is a positive point shown by the treatment, since it was possible conducting degradation by using low hydrogen peroxide concentrations and, consequently, by reducing costs with antioxidants.

Figure 2 - NOM removal efficiency due to the hydrodynamic cavitation phenomenon recorded for different $\mathrm{pH}$ values and peroxide volumes
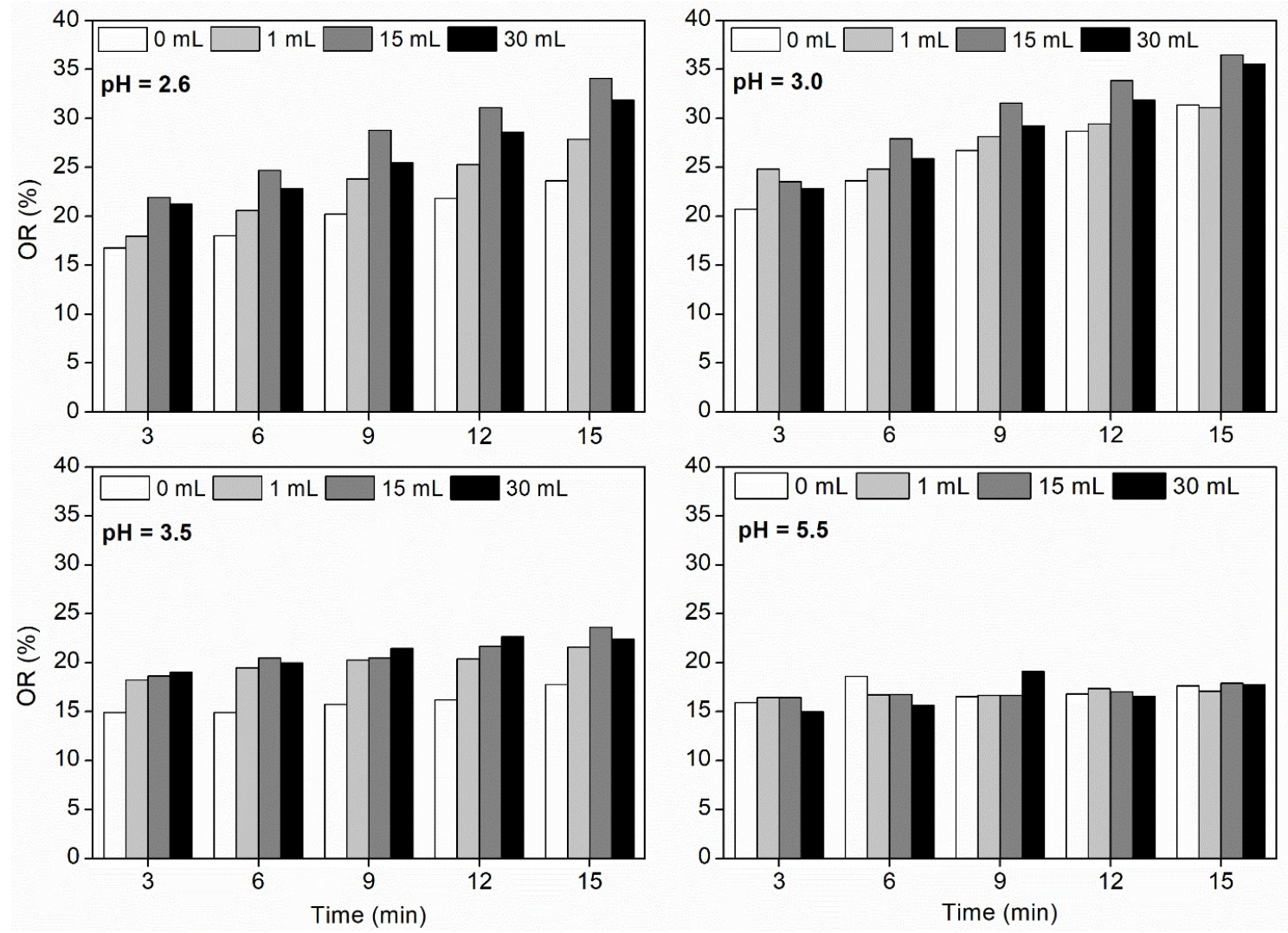

\subsection{Synergic effect evaluation between hydrodynamic cavitation $(\mathrm{HC})$ and hydrogen} peroxide $\left(\mathrm{H}_{2} \mathrm{O}_{2}\right)$

An experiment was carried out in magnetic stirrer (1 Liter and rotation speed of 250 rpm) by using only hydrogen peroxide $\left(\mathrm{pH}=3.0\right.$ and $\left.\mathrm{H}_{2} \mathrm{O}_{2}=1.67 \mathrm{~mL}\right)$ in order to assess the synergic effect $\left(\mathrm{CH}+\mathrm{H}_{2} \mathrm{O}_{2}\right)$ - treated solution remained the same (synthetic humic acid at 100 ppm concentration). NOM removal results in this experiment were compared to results obtained for the maximum efficiency $\left(\mathrm{pH}=3.0\right.$ and $\mathrm{H}_{2} \mathrm{O}_{2}=1.67 \mathrm{~mL} /$ liter of solution) 
observed through hydrodynamic cavitation and hydrogen peroxide. This comparison is shown in Figure 3.

It was possible observing that the isolated effect of hydrogen peroxide has produced low NOM removal rate. The maximum value reached $2.18 \%$ after 15 -min treatment. On the other hand, synergetic effect efficiency $\left(\mathrm{CH}+\mathrm{H}_{2} \mathrm{O}_{2}\right)$ reached $36.48 \%$, which corresponds to increase by 16 times. This outcome can be explained by the fact that the $\mathrm{HC} / \mathrm{H}_{2} \mathrm{O}_{2}$ combination generates more reactive species, reduces mass transfer resistance, and increases turbulence generation (RAUT-JADHAV et al. 2013). Other authors have also reported pollutant degradation increase in case of $\mathrm{HC}$ combined with $\mathrm{H}_{2} \mathrm{O}_{2}$ (ALVES et al., 2019; JOSHI and GOGATE, 2019; SAXENA et al., 2018; MACHADO et al., 2020).

Figure 3 - Comparison between isolated effect applied to hydrogen peroxide and synergic effect between cavitation and hydrogen peroxide for NOM removal

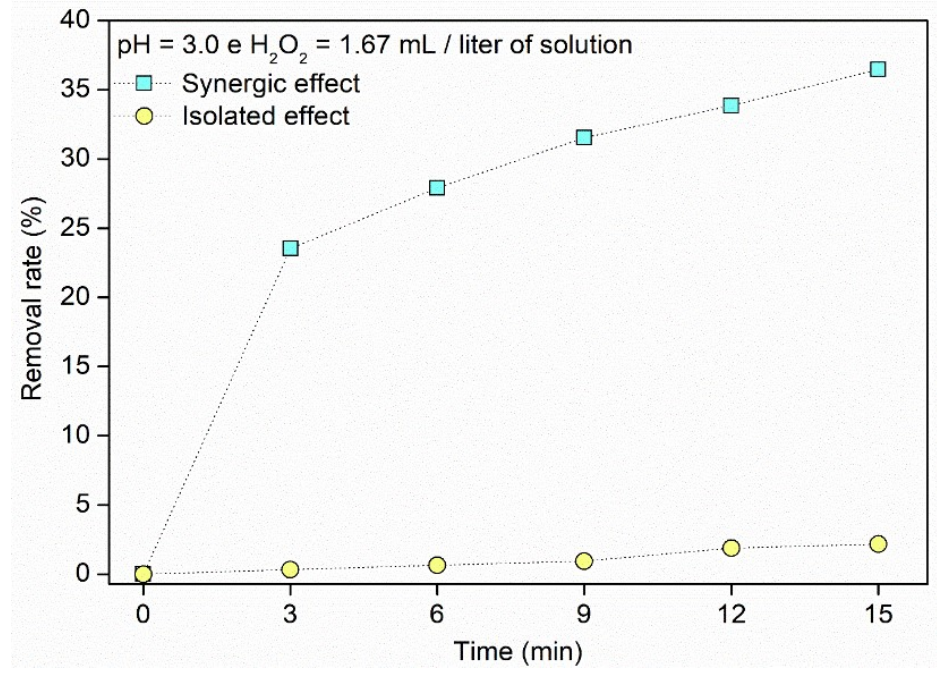

\subsection{NOM removal through hydrodynamic cavitation associated with decantation}

Figure 4 shows NOM removal results obtained after sample decantation. Samples were previously subjected to the hydrodynamic cavitation phenomenon.

It is observed that system efficiency is increased when cavitation is combined with the decantation phenomenon. Notably, the influence of variable $\mathrm{pH}$ stood out: the most acidic $\mathrm{pH}$ rates (2.6 and 3.0) have led to higher efficiency.

Samples of $\mathrm{pH} 2.6$ showed removal efficiency ranging from $82.33 \%(30 \mathrm{~mL}$ of hydrogen peroxide) to $89.77 \%$ ( $1 \mathrm{~mL}$ of hydrogen peroxide) at the 3 -min treatment; however, 
efficiency ranged from $87.71 \%$ ( $0 \mathrm{~mL}$ of hydrogen peroxide) to $91.42 \%$ ( $15 \mathrm{~mL}$ of hydrogen peroxide). This finding suggests the hypothesis that it is possible having high removal efficiency samples after 3-min exposure time.

Samples of pH 3.0 have recorded higher NOM removal efficiency values than samples of $\mathrm{pH} 2.6$, except for the assay that has used $30 \mathrm{~mL}$ of hydrogen peroxide. After the 3-min treatment, NOM removal efficiency ranged from $80.29 \%$ (30 mL of hydrogen peroxide) to $88.32 \%$ ( $0 \mathrm{~mL}$ of hydrogen peroxide). The lowest efficiency recorded for peroxide volume of $30 \mathrm{~mL}$ can be associated with secondary reaction formation, as shown by Machado et al. (2020).

In samples of $\mathrm{pH} 3.5$, the highest efficiencies were recorded when hydrogen peroxide was not added to the treatment - this behavior only took place at this $\mathrm{pH}$. With respect to the sample of $\mathrm{pH} 5.5$, removal efficiencies were close to that of experiments shown in Figure 2.

These results have shown that $\mathrm{pH}$ also has great influence on the decantation phenomenon. Because HS have acid groups ( $\mathrm{RCOOH}$ ) in their complex molecular structures, the partial deprotonation of these groups at $\mathrm{pH} 5.5$ prevail to form anionic structures ( $\mathrm{RCOO}^{-}$ ) that are more hydrophilic and reduce the decantation phenomenon. The groups of acids at $\mathrm{pH} 3.0$ will be protonated due to the prevalence of hydrophobic neutral structures and lead to greater decantation.

Figure 4 - NOM removal efficiency due to hydrodynamic cavitation and decantation phenomena applied to different $\mathrm{pH}$ values and peroxide volumes.

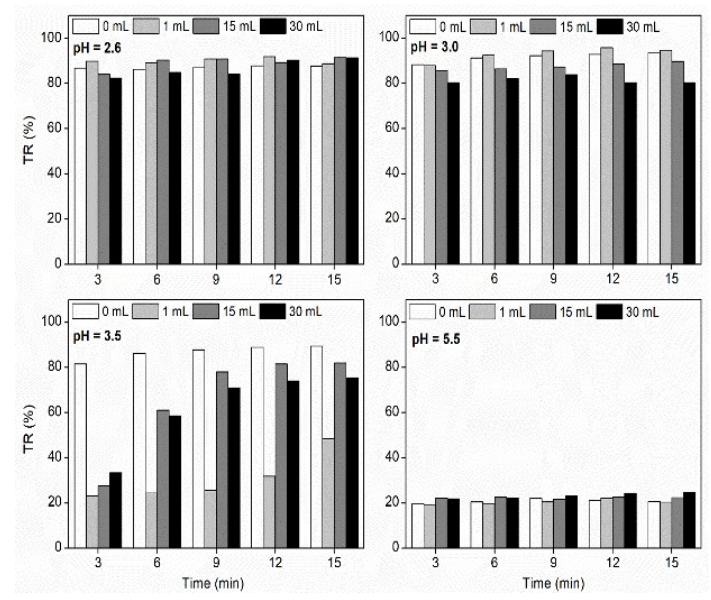


Four aliquots $(50 \mathrm{~mL})$ of humic acid solution, at $100 \mathrm{ppm}$, were left to rest for $24-\mathrm{h}$ in order to assess the isolated effect of decantation. Each aliquot has a pH value of 2.6, 3.0, 3.5, 5.5. After this period-of-time, $15 \mathrm{~mL}$ of supernatant was removed and sent for TOC analysis. It is important highlighting that these samples were treated in the hydrodynamic cavitation system. Figure 5 shows the comparison of results recorded for these samples and the optimum points (maximal removal) of each $\mathrm{pH}$ value shown in Figure 4.

It is possible noticing that decantation takes place regardless of having the sample subjected, or not, to the cavitation system, mainly when $\mathrm{pH}$ is 2.6. However, when the solution is previously treated in the hydrodynamic cavitation, removal efficiency significantly increases due to oxidation. This process takes place because the HC accounts for the oxidation of hydrophilic groups in the HS structure, a fact that increases molecular structure hydrophobicity and intensifies the decantation phenomenon - efficiency increased from $5.50 \%$ to $94.65 \%$ at $\mathrm{pH} 3.0$ (higher NOM removal). Pollutant decantation effect was also observed by Zhang et al. (2012), who have used the Fenton process to remove dissolved organic carbon (DOC) from landfill leachate - removal efficiency due to this process ranged from $9.3 \%$ to $22.6 \%$.

Figure 5 - Comparison between isolated and synergic effect of decantation through hydrodynamic cavitation

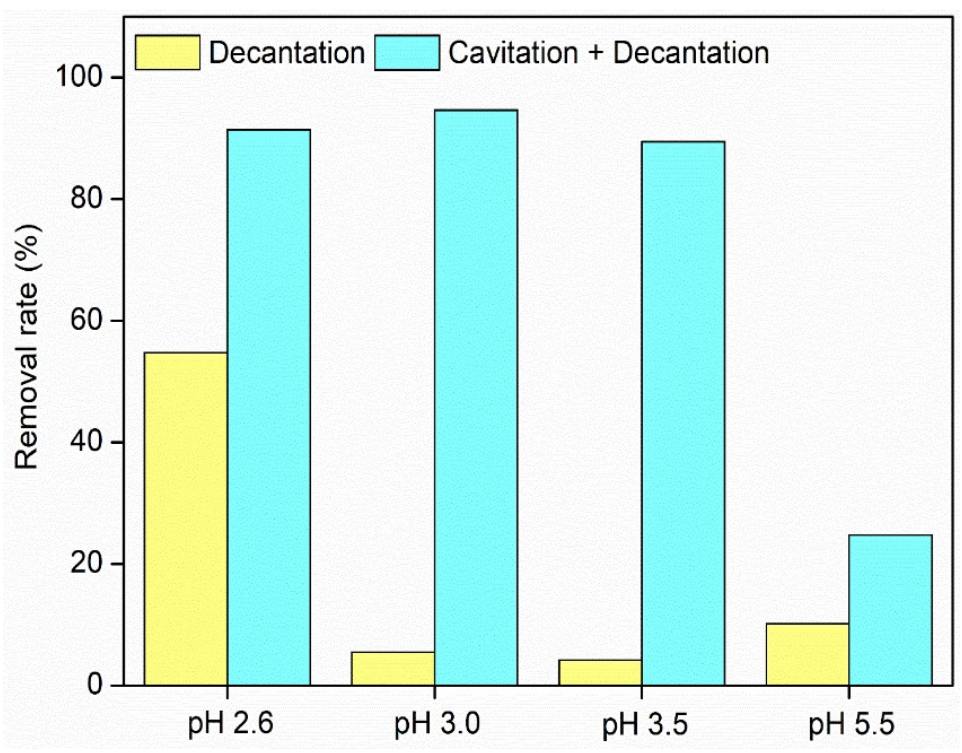




\section{Conclusions}

The aim of the current study was to assess the potential of the hydrodynamic cavitation system associated with hydrogen peroxide to remove NOM from water. The experiments were conducted in experimental apparatus built based on closed circuit. The recorded results made it possible stating that:

- The hydrodynamic cavitation showed high NOM removal potential in samples subjected to the process. The maximum efficiency reached through hydrodynamic cavitation system oxidation was of $36.48 \%$. However, the efficiency profile due to time suggested that it would be possible reaching higher efficiency values if treatment time was longer;

- NOM decantation was potentiated when samples were exposed to the hydrodynamic cavitation process; this outcome has suggested that the hydrodynamic cavitation phenomenon intensified the separation of suspended and dissolved humic species from the liquid medium;

- Variable pH played fundamental role in NOM removal when hydrodynamic cavitation and hydrogen peroxide were used in the experiment. The greatest efficiencies were reached under more acidic conditions ( $\mathrm{pH} 2.6$ and 3.0);

- The optimum volume of hydrogen peroxide was $15 \mathrm{~mL}$ under the adopted experimental conditions. Peroxide excess could produce secondary reactions, which reduces removal efficiency.

Based on the presented results, it was possible observing the need of higher analytical rigor in future studies focused on checking the behavior of chemical species remaining in the reaction medium (NOM and its byproducts). Studies aiming at chromatographic techniques associated with mass spectroscopy can evidence process impacts on the quality of water subjected to the $\mathrm{HC}$ phenomenon. 


\section{Acknowledgment}

Authors are grateful to Pesquisa do Estado de Minas Gerais (FAPEMIG), to Coordenação de Aperfeiçoamento de Pessoal de Nível Superior (CAPES) and to Conselho Nacional de Desenvolvimento Científico e Tecnológico (CNPq) for the financial support.

\section{References}

ALSHEYAB, M. A.; MUÑOZ, A. H. Reducing the formation of trihalomethanes (THMs) by ozone combined with hydrogen peroxide (H2O2/O3). Desalination, v. 194, n. 1-3, p. 121126, 2006.

ALVES, P. H. L.; SILVA, P. S. L.; FERREIRA, D. C.; GONÇALVES, J. C. S. I. COD removal from sucrose solution using hydrodynamic cavitation and hydrogen peroxide: a comparison between Venturi device and orifice plate. Brazilian Journal of Water Resources, v. 24, e.12, 2019.

BAGAL, M. V.; GOGATE P. R. Degradation of 2,4-dinitrophenol using a combination of hydrodynamic cavitation, chemical and advanced oxidation processes, Ultrasonics Sonochemistry, Mumbai, v. 20, n. 5, p. 1226-1235, 2013.

BATISTA, M. D.; ANHÊ, A. C. B. M.; GONÇALVES, J. C. S. I. Use of hydrodynamic cavitation for Algae Removal: effect on the inactivation of microalgae belonging to genus Scenedesmus. Water, Air, and Soil Pollution, v. 228, n.11, p.443, 2017.

CAPPA, O. A. P.; SOEIRA, T. V. R.; SIMÕES, A. L. A.; LOPES JUNIOR, G. B.; GONÇALVES, J. C. S. I. Experimental and computational analyses for induced cavitating flows in orifice plates. Brazilian Journal of Chemical Engineering, 37, p. 89-99, 2020.

$\mathrm{CHOI}, \mathrm{Y}$. Critical flux, resistance and removal of contaminants in ultrafiltration (UF) of natural organic materials. 2003. Tese (Pós-Doutorado), Pennsylvania State University, 2003.

DI BERNARDO, L.; PAZ, L. P. S. Seleção de Tecnologias de Tratamento de Água. São Carlos: Ldibe, 2007.

FILHO, S. S. F.; SAKAGUTTI, M. I. Comportamento cinético do cloro livre em meio aquoso e formação de subprodutos da desinfecção. Engenharia Sanitária e Ambiental, 13:198-206, 2008.

GĄGOL, M.; PRZYJAZNY, A.; BOCZKAJ, G. Wastewater treatment by means of advanced oxidation processes based on cavitation: a review. Chemical Engineering Journal, v. 338, p. 
599-627, 2018. http://dx.doi.org/10.1016/j.cej.2018.01.049.

GOGATE, P. R.; BHOSALE, G. S. Comparison of effectiveness of acoustic and hydrodynamic cavitation in combined treatments chemes for degradation of dye wastewaters. Chemical Engineering and Processing: Process Intensification, v. 71, p.59-69, 2013.

GOGATE, P. R.; KABADI, A. M. A review of applications of cavitation in biochemical engineering/biotechnology. Biochemical Engineering Journal, v. 44, n. 1, p. 60-72, 2009. http://dx.doi. org/10.1016/j.bej.2008.10.006.

ZHANGA, H.; WUA, X.; LIA, X. Oxidation and coagulation removal of COD from landfill leachate by Fered-Fenton process. Chemical Engineering Journal, 210 (2012) 188-194.

JONES, M. N.; BRYAN, N. D. Colloidal properties of humic substances. Advances in Colloid and Interface Science, v. 78, n. 1, p. 1-48, 1998.

JOSHI, S. M.; GOGATE, P. R. Intensification of industrial wastewater treatment using hydrodynamic cavitation combined with advanced oxidation at operating capacity of 70L. Ultrasonics Sonochemistry, v. 52, p. 375-381, 2019.

KATSUMATA, $\mathrm{H}$. et al. Humic acid degradation in aqueous solution by the photo-Fenton process. Chemical Engineering Journal, v. 137, n. 2, p. 225-230, 2008.

LIU, S. et al. Removal of humic acid using $\mathrm{TiO}_{2}$ photocatalytic process - Fractionation and molecular weight characterisation studies. Chemosphere, v. 72, n. 2, p. 263-271, 2008.

MACHADO, P. R.; SOEIRA, T. V. R.; PAGAN, F. S.; MALPASS, G. R. P.; GONÇALVES, J. C. S. I.; FERREIRA, D. C. Synergistic bromothymol blue dye degradation with hydrodynamic cavitation and hydrogen peroxide $\left(\mathrm{HC}-\mathrm{H}_{2} \mathrm{O}_{2}\right)$. Revista Ambiente e Água, v. 15, n.3, 2020.

PATIL, P. N.; BOTE, S. D.; GOGATE, P. R. Degradation of imidacloprid using combined advanced oxidation processes based on hydrodynamic cavitation. Ultrasonics Sonochemistry, v. 21, n. 5, p. $1770-1777,2014$.

PATIL, P. N.; BOTE, S. D.; GOGATE, P. R. Degradation of imidacloprid using combined advanced oxidation processes based on hydrodynamic cavitation. Ultrasonics Sonochemistry, v. 21, n. 5, p. $1770-1777,2014$.

RAJORIYA, S.; BARGOLE, S.; GEORGE, S.; SAHARAN, V. K. Treatment of textile dyeing industry effluent using hydrodynamic cavitation in combination with advanced oxidation reagents. Journal of Hazardous Materials, v.344, p.1109-1115, 2018.

RAUT-JADHAV, S.; BADVE, M. P.; PINJARI, D. V.; SAINI, D. R.; SONAWANE, S. H.; PANDIT, A. B. Treatment of the pesticide industry effluent using hydrodynamic cavitation and its combination with process intensifying additives $\left(\mathrm{H}_{2} \mathrm{O}_{2}\right.$ and ozone). Chemical Engineering 
Journal, v. 112, p. 4505-4514. 2016.

RAUT-JADHAV, S.; SAHARAN, V. K.; PINJARI, D.; SONAWANE, S.; SAINI, D.; PANDIT, A. Synergetic effect of combination of AOP's (hydrodynamic cavitation and $\mathrm{H}_{2} \mathrm{O}_{2}$ ) on the degradation of neonicotinoid class of insecticide. Journal of Hazardous Materials, v. 261, p. 139-147, 2013. http://dx.doi.org/10.1016/j. jhazmat.2013.07.012. PMid:23912079.

SANLY, M. et al. A study on the removal of humic acid using advanced oxidation processes. Separation Science and Technology, v. 42, n. 7, p. 1391-1404, 2007.

SAXENA, S.; SAHARAN, V. K.; GEORGE S. Enhanced synergistic degradation efficiency using hybrid hydrodynamic cavitation for treatment of tannery waste effluent. Journal of Cleaner Production, v. 198, p. 1406-1421, 2018.

SILVA, B. H. L.; MELO, M. A. B. Trihalometanos em água potável e riscos de câncer: simulação usando potencial de interação e transformações de Bäcklund. Quim. Nova, vol. 38, no. 3, 309-315, 2015.

SILVA, P. DE S. L.; MATEUS, M. V.; FERREIRA, D. C.; LUZ, M. S.; NAVES, E. A. A.; MARTINS, M. M.; GOULART, L. R.; CUNHA, L. C. S.; GONÇALVES, J. C. S. I. Humic substances reduce the oxygen mass transfer in the air-water interface. AlChE J. 2020;66:e16971.https://doi.org/10.1002/aic.16971.

ŚWIETLIK, J. et al. Reactivity of natural organic matter fractions with chlorine dioxide and ozone. Water Research, v. 38, n. 3, p. 547-558, 2004.

THURMAN, E. M. Organic Geochemistry of Natural Waters. Dordrecht: Martinus Nijhoff/dr. W. Junk Publishers, 1985.

ZHANG, X. et al. $\mathrm{TiO}_{2}$ nanotube photocatalytic oxidation for water treatment. WaterScience and Technology: Water Su 